\title{
Aby Warburg e nós
}

Pedro Paulo Pimenta

É mais do que apropriado que a revista Discurso dedique espaço à obra de Aby Warburg (1866-1929), que pela primeira vez é publicada no Brasil em traduções feitas diretamente do alemão. Não custa reiterar, para uso dos mais jovens, que esta revista foi fundada nos idos de 1970 por Gilda de Mello e Souza (1919-2005), e essa grande representante do pensamento crítico moderno brasileiro tinha Warburg em alta estima. É o que mostra um importante artigo de Otília Arantes, publicado há dez anos, intitulado "Nota sobre o método crítico de Gilda de Mello e Souza":

... é nesse vai e vem entre a pintura, sua história e a realidade que se move a nossa autora - utilizando permanentemente e ao mesmo tempo relativizando as lições dos mestres da Escola de Warburg. Não eram poucas as referências em aula às dobras das roupas ou à postura dos serviçais nas pinturas dos holandeses, tanto quanto ao tratamento homogeneizador das figuras na tela e os objetos da vida doméstica daqueles interiores - veja-se A leiteira, de Vermeer; ou à carna- 
dura lisa, polida como os belos corpos das esculturas gregas ou mesmo como as estatuetas de biscuit, das figuras femininas de um Ingres, tão distantes da realidade e tão racionalmente construídas - exemplares justamente do contraste entre o linear e o pictórico na pintura, da diferença entre clássicos e românticos, Ingres e Delacroix ou Géricault ${ }^{1}$.

Trata-se, portanto, da absorção crítica de procedimentos de método cultivados por toda uma tradição que, surgida na Alemanha na década de 1910, é transplantada, por ocasião da barbárie nazista, para a Inglaterra. Desnecessário acrescentar que a passagem de Otília Arantes sutilmente remete o leitor, pelo conteúdo como pelo método a que se refere, a $O$ espírito das roupas, que conta entre os principais escritos de Gilda de Mello e Souza ${ }^{2}$. Como observa Otília Arantes no mesmo artigo, a dívida de Gilda para com a Escola de Warburg está diretamente ligada à leitura da obra de Ernst Gombrich, que assim resume o método de seu mestre:

A história da arte não deveria se preocupar com a evolução estilística em abstrato e sim com seres humanos reais, que, tendo de tomar decisões, procuram guiar-se tanto pelo passado como pelo presente. A essa convicção devemos a Biblioteca Warburg. Pois Warburg sabia que a biblioteca com que o historiador da arte normalmente trabalha, com suas obras de referência e monografias, é inteiramente insuficiente para

\footnotetext{
${ }^{1}$ Otília Arantes, "Nota sobre o método crítico de Gilda de Mello e Souza", in: Estudos avançados, 20 (56), 2006, p. 315.

${ }^{2}$ Gilda de Mello e Souza, $O$ espírito das roupas. A moda no século XIX, $2^{\text {a }}$ edição, São Paulo: Companhia das Letras, 2005.
} 
a realização de um programa de pesquisa tal como o que traçara para si. Seu mote era "A palavra à imagem" (Das Wort zum Bild). Não poderíeis trabalhar a respeito de Botticelli sem o texto de Poliziano a vosso lado e sem descobrir como viviam seus patronos ${ }^{3}$.

A resenha aqui incluída, de autoria de Lênin Bicudo Bárbara - ele mesmo tradutor de uma coletânea de textos de Warburg (Histórias de fantasma para gente grande. Escritos, esboços e conferências, São Paulo: Companhia das Letras, 2015) - contempla não somente outra tradução, surgida pouco antes da sua, como também dois volumes de literatura crítica também recentemente publicados. Já a tradução, por Isabel Coelho Fragelli, da bela conferência de Ernst Cassirer em homenagem a Warburg, pronunciada em 1929 por ocasião da morte deste, vem lembrar que, entre história da arte e filosofia, a aliança é às vezes mais próxima do que muitos poderiam suspeitar.

${ }^{3}$ Ernst Gombrich, "The ambivalence of classical tradition. The cultural psychology of Aby Warburg", in: Tributes. Interpreters of our cultural tradition, Oxford: Phaidon, 1984, p. 123. 
